\title{
An Excursion into the History of Chromatography: Mikhail Tswett, From Asti, Italy, to Tartu, Estonia
}

\author{
Jean-François Gal ${ }^{1}$ iD \\ Published online: 8 January 2019 \\ c) Springer-Verlag GmbH Germany, part of Springer Nature 2019
}

In 2010, in this Journal, I described two memorials in Tartu, Estonia, honouring scientists who worked on the development of chromatography, Teodor Lippmaa and Mikhail Semyonovich Tswett ${ }^{1}$ (Михаил Семёнович Цвет) [1]. The University of Tartu, founded in 1632 and reopened after various vicissitudes in $1802,{ }^{2}$ has a long tradition in science and chemistry [2]. Its reopening took place under the initiative of George-Frederic Parrot [3], a German-speaking mathematician, physicist and chemist born in France. ${ }^{3}$

As reported in my 2010 note, during visits to the University of Tartu, I discovered a plaque (Fig. 2) in the University botanical garden (Fig. 1) commemorating the contribution of Mikhail Tswett to the Tartu Botanical Garden in 1917 and 1918. This, unfortunately too short, period of work in Tartu was due to the perturbations of the First World War and the poor physical condition of Mikhail Tswett. However, on March 24, 1917, he was appointed as professor of botany and director of the Botanical Gardens at the University of Tartu [4, 5]. It is interesting to note that Mikhail Tswett's father, Semen Nikolaevich Tswett, had studied science at University of Tartu, which was held in high esteem in the Tswett family [6]. When Tartu was invaded by German troops in 1918, Mikhail Tswett left Tartu to Voronezh, Russia, where the University was relocated. He died in Voronezh on June 26, 1919, at the age of 47 . This was a period of

Mikhail Semyonovich Tswett: on the occasion of the centenary of his death, June 26, 1919.

Jean-François Gal

jean-francois.gal@univ-cotedazur.fr

1 Université Côte d'Azur, CNRS, Institut de Chimie de Nice, UMR 7272, 06108 Nice, France great political instability, the independence of Estonia was declared in 1918, and 1919 was the year of foundation of the first Estonian-language university, the centenary of which will be officially celebrated on the 1 st of December $2019 .{ }^{4}$

Not long after the publication of my note [1], I was visiting Asti, Italy, a town well known for wines and for its Palio, a dangerous bareback horse race run within the city. By chance, or by the so-called "serendipity", I discovered a plaque commemorating the centenary of the birth of the discoverer of chromatography, Fig. 3, as noted in the commemorative inscription. My curiosity was excited and I would like to share my discovery.

This landmark celebrating Mikhail Tswett birth is situated under the arcades (Portici Pogliani) of Piazza Vittorio Alfieri, $\mathrm{N}^{\circ} 5$, about $4 \mathrm{~m}$ from the ground, close to the entrance of Hotel Reale (Royal Hotel). Just near the hotel entrance and the plaque, at $\mathrm{N}^{\circ} 3$, a historical pharmacy is also worth a stop, ${ }^{5}$ (Fig. 4), bearing in mind the remarkable "chemical affiliation" with the Tswett discovery of chromatography.

Hotel Reale, still in operation, is the exact place where Tswett was born on May 14, 1872. I was not able to collect more information among the Italian chemists' community on the initiators and origin of this tribute. The birth of Mikhail Tswett was reported at the town hall on May 19, a date which is sometimes mistakenly reported

\footnotetext{
1 The English transcription of the Cyrillic Цвет is Tsvet, but the German transcription Tswett is mostly used; other transcriptions found in historical and scientific articles are Tsvett, Tswet, Zwet, and Cvet. The patronymic name (father's name) Семёнович is often transcript as Semenovich.

${ }^{2}$ From 1802 to 1893 , the teaching language at UT is German, the German name of Tartu being Dorpat. After the independence of Estonia, Estonian becomes the official language of the University. Russian biographers often mention the use of the former Russian name Yuriev (or Yur'ev) for Tartu.

3 The program of bilateral scientific exchanges between Estonia and France received the name of Parrot.

${ }^{4}$ https://www.ut.ee/en/estoniasnationaluniversity 100.

5 This famous pharmacy was moved from the hospital of Santa Marta in 1867, and the owners keep old pharmacy tools and pharmacopeias; see its Facebook site.
} 


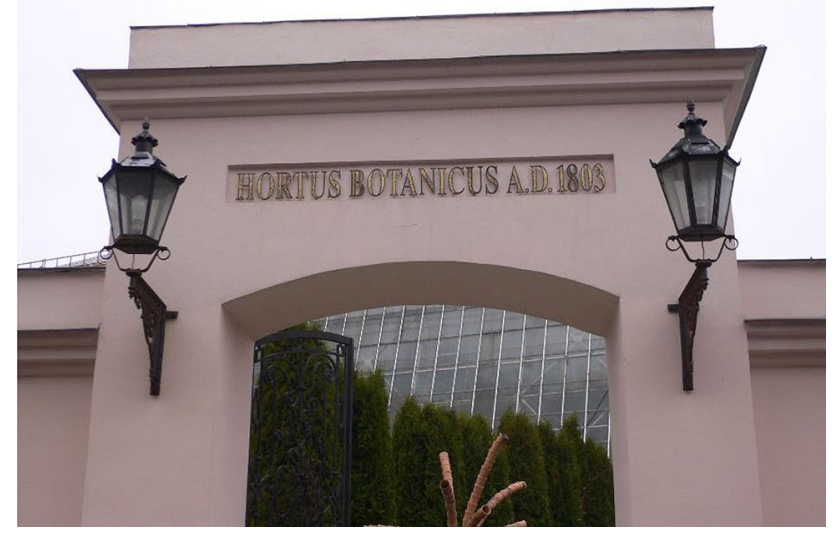

Fig. 1 Entrance of the botanical garden of the University of Tartu

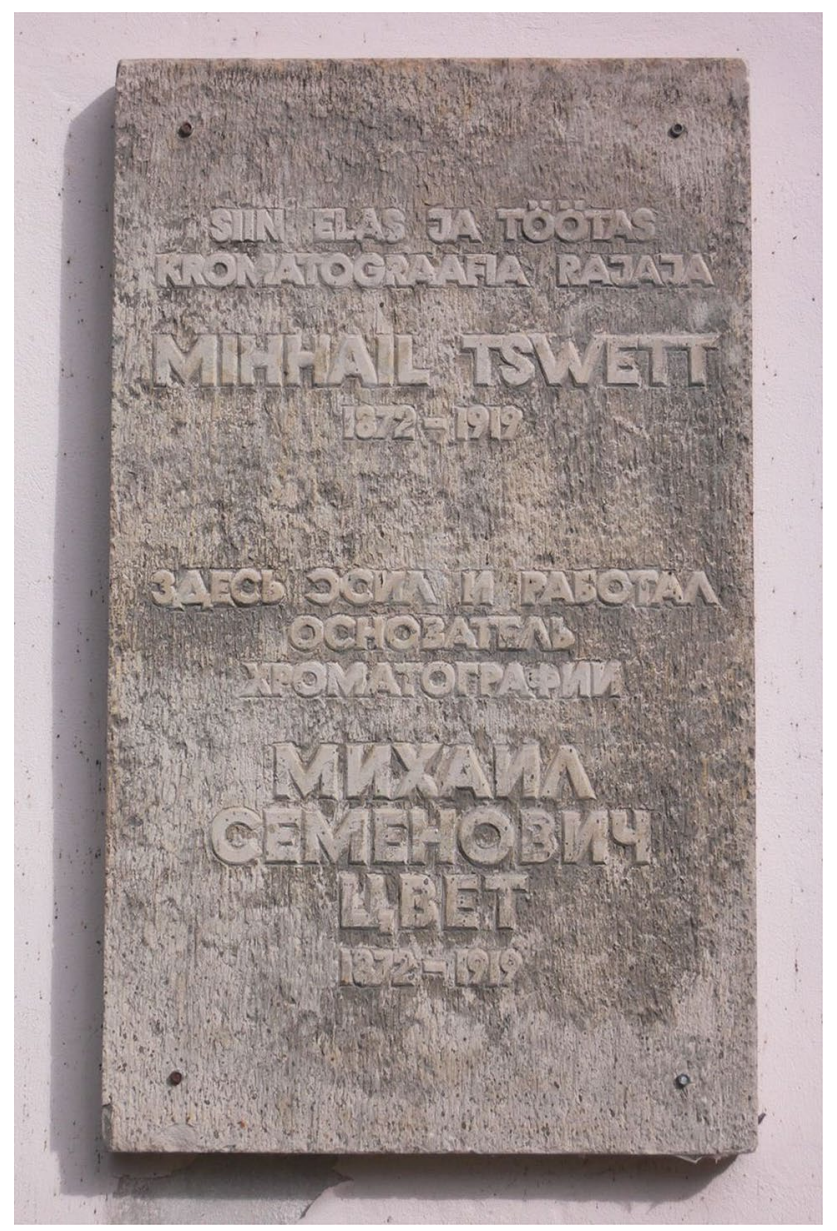

Fig. 2 Plaque honouring Mikhail Tswett (1872-191), in Estonian and Russian, botanical garden of the University of Tartu: "here lived and worked the founder of chromatography"

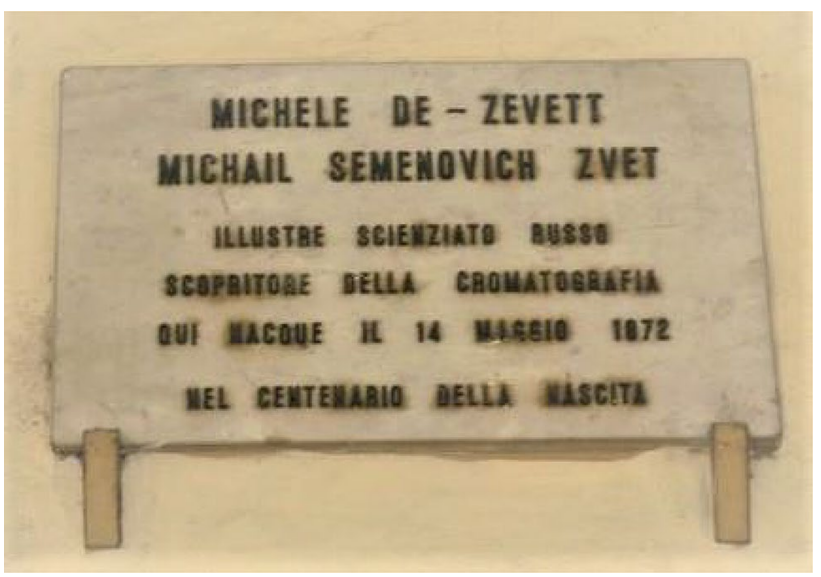

Fig. 3 Commemorative plaque of the birth of M. S. Tswett (spelled in Italian in two ways) at $\mathrm{N}^{\circ} 5$ of Piazza Vittorio Alfieri (under the arcade-covered passage "Portici Pogliani", close to the entrance of Hotel Reale) in Asti, Region of Piedmont, Italy. The Italian text is: "Michele De-Zevett, Michail Semenovich Zvet, Illustre Scienziato Russo, Scopritore della Cromatographia, Qui Nacque il 14 Maggio 1872, Nel Centenario della Nascita" (Illustrious Russian scientist-discoverer of chromatography—who was born here on 14 May 1872 - on the centenary of the birth)

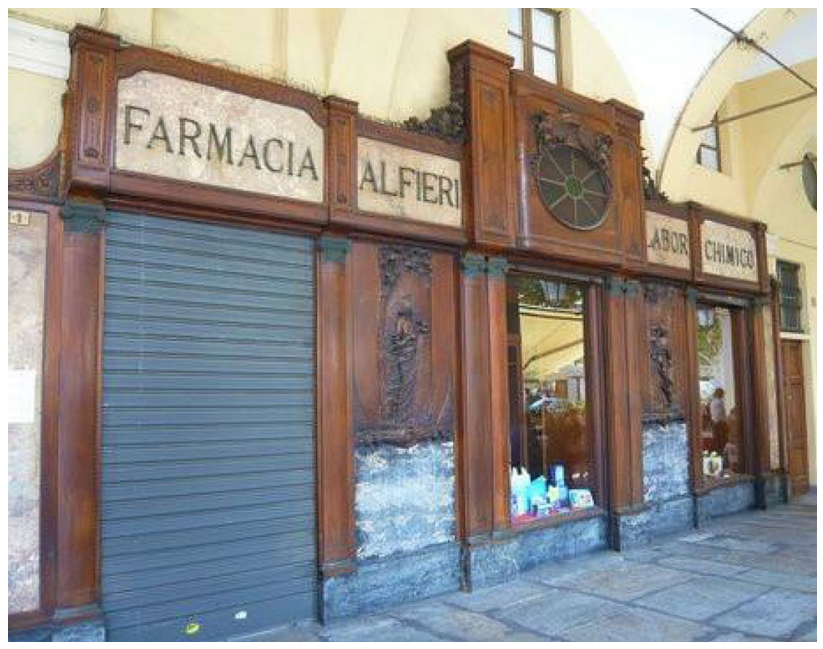

Fig. 4 The remarkable "Farmacia Alfieri-Labor Chimico" under the Portici Pogliani, $\mathrm{N}^{\circ} 3$ Piazza Vittorio Alfieri, is near the Tswett plaque

as his birthday. His parents had come from Russia by ship to Genoa (Italy, Liguria), and arrived in Asti by train. They planned to spend an extended holiday in a resort at the beautiful Lake Maggiore, but the family had to stop urgently because of premature labour of the pregnant mother, Maria de Dorozza, of Italian origin. The birth appeared to have been difficult, and Maria died shortly after [7]. Little is known on the life of the mother [8]. The father took his premature and weak baby to Lausanne, Switzerland, where Mikhail Tswett was raised by a nurse. 
In 1885 Mikhail Tswett moved to Geneva [8], where he graduated from high school in 1891 and obtained his doctoral degree in 1896 [4].

Before his short period in Tartu, Tswett started a teaching career at St. Petersburg, Russia, then became an assistant at the University of Warsaw, Poland, and, later in the same University, professor of botany and agronomy at the Veterinary Institute, and professor of botany and microbiology at the Polytechnic Institute $[8,9] .{ }^{6} \mathrm{Sev}-$ eral detailed accounts of his life, scientific achievements and difficulties in his career are available [4-14]. Two authors, Karl I. Sakodynskii (1930-1996) [15] and Leslie S. Ettre (1922-2010) [16] were the most prolific Tswett's biographers.

Mikhail Tswett and Teodor Lippmaa were initially botanists, [17] but became recognized later by the chemist community. It is surprising that Tswett and Lippmaa are not cited in a history of analytical chemistry in Estonia covering the 19th and half of the twentieth century [18]. Fortunately, Tswett was cited in another account on the chemistry and chemistry-related sciences in Tartu [2]. Indeed, Mikhail Tswett was nominated for the Nobel Prize in 1918 [5].

Finally, it is notable that Asti and Tartu are the towns in which began and almost ended the life of Mikhail Semyonovich Tswett.

Acknowledgements I greatly appreciated the stylistic suggestions of my colleague Professor Pierre-Charles Maria, Université Côte d'Azur, and the exchanges with Professor Peeter Burk, University of Tartu.

\section{Compliance with ethical standards}

Conflict of interest The author declares that he has no conflict of interest.

Ethical approval This article does not involve research with human participants and/or animals.

\section{References}

1. Gal J-F (2010) A short note on the history of chromatography at the University of Tartu, Estonia. Chromatographia 72:203-204
2. Lenoir D (2009) Eliteuniversität des 19. Jahrhunderts" (Elite University of the 19th century). Nachrichten Chem 57:1100-1103; see also https://www.chem.ut.ee/en/about-institute/history, with links to two pdf files (accessed 21/09/2018); (i) Ilomets T, "Chemistry and Chemistry-Related Sciences at Tartu (Dorpat) University in 1802-1919"; (ii) Past V, "Chemistry at the University of Tartu in 1919-1947

3. Allik J, Konstabel K (2005) G. F. Parrot and the theory of unconscious inferences. J Hist Behav Sci 41:317-330

4. Ettre LS, Sakodynskii KI (1993) M. S. Tswett and the discovery of chromatography I: early work (1899-1903). Chromatographia 35:223-231

5. Ettre LS (1996) M. S. Tswett and the 1918 nobel prize in chemistry. Chromatographia 42:343-351

6. Hais IM (1988) Tswett's letters to Claparède. J Chromatogr 440:509-531

7. Ettre LS (2003) M. S. Tswett and the Invention of chromatography. LC GC Eur 21(2-7):458-467 (published also in LC•GC North America, 2003)

8. Sakodynskii KI (1981) New data on M. S. Tswett's life and work. J Chromatogr 220:1-28

9. Zolotov YuA (2003) The centenary of chromatography. J Anal Chem 58:703-705. (Translated from the Russian edition Zhur. Anal. Khim. 2003, 58, 789-791)

10. Strain HH, Sherma J (1967) Michael Tswett's contributions to sixty years of chromatography. J Chem Educ 44:235-237

11. Sakodynskii KI (1970) M. S. Tswett - his Life and Work. Chromatographia 3:92-94

12. Sakodynskii KI, Chmutov K (1972) M. S. Tswett chromatography. Chromatographia 5:471-476

13. Berezkin VG (1989) Biography of Mikhail Semenovich Tswett and translation of Tswett's preliminary communication on a new category of adsorption phenomena. Chem Rev 89:279-285

14. Livengood J (2009) Why was M. S. Tswett's chromatographic adsorption analysis rejected? Studies History Phil Sci 40:57-69

15. Ettre LS (1996) In Memoriam K. I. Sakodynskii (1930-1996). Chromatographia 42:615-616

16. Adlard T (2010) Leslie Stephen Ettre 1922-2010. Chromatographia 72:201-202

17. Sander H, Meikar T, Magowska A (2014) The learned gardeners of the botanical gardens of the University of Tartu and their activities (1803-1918). Acta Baltica Hist Sci 2:53-110

18. Hödrejärv H (1997) History of analytical chemistry in Estonia (1800-1950). Fresenius J Anal Chem 357:191-196

Publisher's Note Springer Nature remains neutral with regard to jurisdictional claims in published maps and institutional affiliations.

\footnotetext{
${ }^{6}$ Pictures of a memorial plaque celebrating the invention of chromatography by Mikhail Tswett (1901-1906), and of the building of the Warsaw University on which this plaque is placed are shown in Ref [9].
} 